\title{
Biomechanical Influence of Start Technique Preference for Elite Track Starters in Front Crawl
}

\author{
J. Vantorre ${ }^{1}$, L. Seifert ${ }^{1}$, R.J. Fernandes ${ }^{2, *}$, J.P. Vilas-Boas ${ }^{2}$ and D. Chollet $^{1}$ \\ ${ }^{I}$ CETAPS. EA 3832, University of Rouen, Faculty of Sports Sciences, France \\ ${ }^{2}$ CIFI2D, Faculty of Sport, University of Porto, Portugal
}

\begin{abstract}
The aim of this study was to analyse the differences between preferential and non preferential start technique, and the inter-trial variability. Seven elite swimmers, who used track start as preferential technique, realised three trials in track and grab start. The kinematical analysis assessed the durations of the block, flight, entry, glide, leg kicking and full swimming phases to the 15-m mark. Aerial (sum of block and flight phase with head mark) and underwater (from entry to the head reach the water surface) phases, number of underwater leg undulations and arm stroke to $15 \mathrm{~m}$ were also measured. The kinetic analysis assessed reaction and impulse time and total impulses in vertical and horizontal axis. Track start, as preferential technique, had shorter block and entry phases but similar flight phase. In grab start, swimmers spend more time in the impulse and obtained higher vertical impulse values; moreover higher inter-trial variability was found for non-preferential technique suggesting lower efficiency. Differences of kinematics and kinetics observed tended to explain that the preferential technique is highly stabilised and reproducible by the swimmers. However, no differences on the $15 \mathrm{~m}$ start time performance are observed between the two techniques, confirming the high skill level of the swimmers, and notably their capability to compensate lower block efficiency by effective underwater phases. Indeed, the relative duration of the underwater phases, the number of leg undulations and arm strokes are very similar in both techniques.
\end{abstract}

Keywords: Biomechanics, expertise, preferential technique, swimming start.

\section{INTRODUCTION}

Several studies have quantified the start time in relation to swim and to turn times, to assess its contribution to overall competition performance $[1,2]$. The findings indicate that $15 \mathrm{~m}$ start times last from $0.8 \%$ to $26.1 \%$ of overall race duration (depending on the event), suggesting the interest of the study of this topic in swimming [2,3]. Most of the biomechanical studies of start time have used kinetic and kinematical analyses to compare the two main start techniques used in competition: the grab and the track starts. VilasBoas et al. [4] observed faster reaction time, higher impulse time, greater flight distance and shorter glide time in the grab start comparing to the track start. Using a track start, swimmers tend to leave the block quicker [5] and to make a flatter flight trajectory due to higher horizontal velocity [6]. With the grab start, swimmers spend more time on the block [7].

The above-referred studies tried to observe which is the best starting technique to increase performance. However, studies that analysed differences between start techniques that takes in consideration the swimmers start preference are scarce [4]. Knowing that the use of preferential technique may induce better performance to $15 \mathrm{~m}$, as well as less variability of performance due to better technical management, the aim of this study was to compare kinematical and kinetic

*Address correspondence to this author at the Ricardo Fernandes, Faculty of Sport, Porto University, Porto Portugal; Tel: +351 225074763;

Fax: +351 2255000687; E-mail: Ricfer@fade.up.pt start parameters between preferential and non preferential techniques, and to compare its variability.

\section{METHODS}

Seven elite male swimmers, specialists in front crawl sprint, participated in this study. Their main physical characteristics were: $21.7 \pm 5.5$ years old, $1.87 \pm 0.07 \mathrm{~cm}, 82.1 \pm 7.7 \mathrm{~kg}$, $53.60 \pm 3.48 \mathrm{~s}$ in the $100 \mathrm{~m}$ freestyle long course (which corresponds to $89.37 \pm 5.66 \%$ of the world record). Track start technique was their preferential technique.

In a $25 \mathrm{~m}$ swimming pool, each swimmer performed $6 \times 25 \mathrm{~m}$ front crawl at the $50 \mathrm{~m}$ race pace, being three repetitions using the track start, and three using the grab start techniques. The first camera $(50 \mathrm{~Hz})$ was placed from the edge of the pool and videotaped the take-off and flight phases. Two other cameras $(50 \mathrm{~Hz})$ were mounted on a specially designed support placed at the lateral wall $3 \mathrm{~m}$ from the edge of pool deck (one above the water and the other kept underwater), videotaping the entry and underwater phases. Two lateral mobile cameras $(50 \mathrm{~Hz})$ were fixed on a trolley and were connected to double-entry visual mixing table.

The kinematical analysis of the start (to the $15 \mathrm{~m}$ mark) included the block, flight, entry, glide, leg kicking and swimming phases. The number of underwater leg undulations and of arm stroke movements to $15 \mathrm{~m}$ were added to characterize quantitatively the start. Additionally, the aerial phase was composed by the block and flight phases (with head mark), while the underwater phase was composed by the entry and glide phases, and the propulsion until the head reach the water surface. 
Table 1. Absolute and Relative Values of the Start Phases and Kinetic Parameters and their Correlations with Start Time Among the 2 Techniques.

\begin{tabular}{|c|c|c|c|c|c|c|c|c|c|c|c|c|c|c|c|}
\hline & $\begin{array}{c}\text { Block } \\
\text { Phase } \\
\text { (s) }\end{array}$ & $\begin{array}{c}\text { Flight } \\
\text { Phase } \\
\text { (s) }\end{array}$ & $\begin{array}{c}\text { Entry } \\
\text { Phase } \\
\text { (s) }\end{array}$ & $\begin{array}{c}\text { Glide } \\
\text { Phase } \\
\text { (s) }\end{array}$ & $\begin{array}{l}\text { Leg Kicking } \\
\text { Phase } \\
\text { (s) }\end{array}$ & $\begin{array}{c}\text { Swimming } \\
\text { Phase } \\
\text { (s) }\end{array}$ & $\begin{array}{c}\text { Number of } \\
\text { Underwater } \\
\text { leg } \\
\text { Undulations }\end{array}$ & $\begin{array}{c}\text { Number of } \\
\text { Arm Stroke } \\
\text { Movements } \\
\text { to } 15 \mathrm{~m}\end{array}$ & $\begin{array}{c}\text { Aerial } \\
\text { Phase } \\
\text { (s) }\end{array}$ & $\begin{array}{c}\text { Underwater } \\
\text { Phase } \\
\text { (s) }\end{array}$ & $\begin{array}{c}\text { Start } \\
\text { Time } \\
(\mathrm{s})\end{array}$ & $\begin{array}{c}\text { Reaction } \\
\text { Time } \\
\text { (s) }\end{array}$ & $\begin{array}{c}\text { Impulse } \\
\text { Time } \\
\text { (s) }\end{array}$ & $\begin{array}{c}\text { Impulse } \\
\text { Horizonta } \\
\text { l Axis } \\
\text { (Ns) }\end{array}$ & $\begin{array}{c}\text { Impulse } \\
\text { Vertical Axis } \\
\quad(\mathrm{Ns})\end{array}$ \\
\hline Track start & $0.89 \pm 0.07$ & $0.30 \pm 0.05$ & $0.32 \pm 0.03$ & $0.27 \pm 0.12$ & $1.93 \pm 0.74$ & $2.86 \pm 0.85$ & $4.9 \pm 1.7$ & $6.2 \pm 1.5$ & $1.20 \pm 0.07$ & $2.52 \pm 0.81$ & $6.6 \pm 0.3$ & $0.20 \pm 0.02$ & $0.69 \pm 0.05$ & $218.4 \pm 24.5$ & $835.8 \pm 87.8$ \\
\hline Track start (\%) & $13.7 \pm 1.2$ & $4.6 \pm 0.9$ & $4.9 \pm 0.6$ & $4.1 \pm 1.8$ & $29.3 \pm 11$ & $43.4 \pm 12.7$ & & & & & 100 & & & & \\
\hline Grab start & $0.98 \pm 0.09$ & $0.29 \pm 0.05$ & $0.34 \pm 0.04$ & $0.28 \pm 0.14$ & $1.98 \pm 0.83$ & $2.65 \pm 0.86$ & $4.9 \pm 1.9$ & $6 \pm 1.67$ & $1.28 \pm 0.07 *$ & $2.61 \pm 0.91$ & $6.5 \pm 0.3$ & $0.20 \pm 0.03$ & $0.78 \pm 0.05^{*}$ & $210.4 \pm 28.6$ & $937.2 \pm 138.1^{*}$ \\
\hline Grab start (\%) & $15.1 \pm 1.4^{*}$ & $4.5 \pm 0.8$ & $5.3 \pm 0.7^{*}$ & $4.3 \pm 2.3$ & $30.2 \pm 11.9$ & $40.7 \pm 13$ & & & & & 100 & & & & \\
\hline Statistics & $\begin{array}{l}F(1,41) \\
=62.22\end{array}$ & & $\begin{array}{c}\mathrm{F}(1,41) \\
=5.90\end{array}$ & & & & & & $\begin{array}{l}\mathrm{F}(1,41) \\
=31.25\end{array}$ & & & & $\begin{array}{l}\mathrm{F}(1,41) \\
=23.30\end{array}$ & & $\begin{array}{l}F(1,41) \\
=5.77\end{array}$ \\
\hline $\begin{array}{l}\text { Correlations } \\
\text { with Start Time }\end{array}$ & $\begin{array}{l}r=-0,31 \\
p=0,05\end{array}$ & $\begin{array}{l}\mathrm{r}=-0,31 \\
\mathrm{p}=0,05\end{array}$ & $\begin{array}{l}r=-0,43 \\
p=0,01\end{array}$ & & & & & & & & & & & & \\
\hline
\end{tabular}

* significant difference with the Track Start at $\mathrm{p}<0.05$.

Table 2. Intra Class Correlations and Variability for Start Phases Among the 2 Techniques.

\begin{tabular}{|c|c|c|c|c|c|c|c|c|c|c|c|c|c|}
\hline & $\begin{array}{l}\text { Block } \\
\text { Phase }\end{array}$ & $\begin{array}{l}\text { Flight } \\
\text { Phase }\end{array}$ & $\begin{array}{l}\text { Entry } \\
\text { Phase }\end{array}$ & $\begin{array}{l}\text { Glide } \\
\text { Phase }\end{array}$ & $\begin{array}{l}\text { Leg Kicking } \\
\text { Phase }\end{array}$ & $\begin{array}{c}\text { Swimming } \\
\text { Phase }\end{array}$ & Aerial Phase & $\begin{array}{l}\text { Underwater } \\
\text { Phase }\end{array}$ & $\begin{array}{l}\text { Start } \\
\text { Time }\end{array}$ & $\begin{array}{c}\text { Reaction } \\
\text { Time }\end{array}$ & Impulse Time & $\begin{array}{c}\text { Impulse } \\
\text { Horizontal } \\
\text { Axis }\end{array}$ & $\begin{array}{c}\text { Impulse } \\
\text { Vertical Axis }\end{array}$ \\
\hline Track Start & 0.94 & 0.92 & 0.44 & 0.85 & 0.93 & 0.93 & 0.90 & 0.95 & 0.90 & 0.82 & 0.81 & 0.82 & 0.79 \\
\hline Grab Start & 0.84 & 0.87 & 0.37 & 0.74 & 0.93 & 0.92 & $0.70^{*}$ & 0.95 & 0.61 & 0.67 & 0.51 & 0.65 & $0.77 *$ \\
\hline $\begin{array}{l}\text { Statistics on } \\
\text { SD and CV }\end{array}$ & & & & & & & $\begin{array}{l}\text { SD: } F=10.1 \\
C V: F=8.34\end{array}$ & & & & & & $\begin{array}{c}\text { SD: } F=7.9 \\
C V: F=4.86\end{array}$ \\
\hline
\end{tabular}

\footnotetext{
* significant difference with the Track Start at $\mathrm{p}<0.05$.
} 
Concerning kinetic analysis, starts were evaluated using a Bertec 4060-15 force plate mounted on a specially built support fixed to the pool wall that allowed a starting position conforming to swimming rules. The sampling rate was $1000 \mathrm{~Hz}$. The analogical signal was transmitted to a PC through a Biopac A/D converter [4]. Starting signal was in accordance to the swimming rules and was produced by a starter device (ProStart). After filtering and smoothing (low pass, $80 \mathrm{~Hz}$ ), reaction time, impulse time and impulses values were obtained in the 3 dimensions from force plate. Only horizontal and vertical axes (direction of the movement) were analysed.

The differences between the preferential (track start) and non-preferential (grab Start) techniques have been analysed by ANOVA with repeated measure. Pearson correlation and stepwise regression analysis studied the relationship among the start parameters and the $15 \mathrm{~m}$ start time for the whole population. The level of significance accepted was set at 0.05 . The inter-trial variability was assessed by the calculation of Intra Class Correlations between the three trials for all the subjects for each technique [8]. The inter-trial variability was also assessed by ANOVA, which determine the differences of standard deviation and coefficient of variation within techniques.

\section{RESULTS}

From a kinematical analysis, it was possible to observe in (Table 1) the comparison between preferential and non preferential techniques in the block, entry and swimming phases. For instance, the track start had shorter block and entry phases but similar flight phase.

Regarding the kinetic parameters, it is observable that when using the grab start, the swimmers spend more time in the impulse and obtained higher vertical impulse values. Additionally, block, flight and entry phase's durations were negatively correlated with total start time.

For inter-trial variability (cf. Table 2), the results revealed excellent reliability among the three trials in all phases, except entry phase in track start (fair reproducibility), evidencing higher values for preferential technique than to non preferential technique. Analysis of coefficient of variation and standard deviation showed differences between the two start techniques for the aerial phases and vertical impulse on the block. Notably, the standard deviations (SD) and the coefficient of variation (CV) were higher for the non-preferential than for the preferential technique: for the aerial phases (SD: 0.036 vs. 0.019 and CV: 2.82 vs. 1.54 , respectively) and for vertical impulse (SD: 53.0 vs. 39.9 and CV: 5.36 vs. 4.79 , respectively).

\section{DISCUSSION}

The track start, being the preferential technique of our subjects, showed that for shorter block phase and impulse time for similar flight time, suggesting a better aerial phases efficiency. Indeed, values of impulse showed lower efficiency in non-preferential technique with higher value of impulse in vertical axis and a tendency to a smaller value of impulse in the horizontal axis, suggesting that the impulse is less oriented with the non-preferential technique.

Results of standard deviation and coefficient of variation indicated greater variability for the duration of aerial phases and the vertical impulse on the block for the non-preferential technique. These results confirm the differences of kinematics and kinetics observed previously and support that the preferential technique is highly stabilised and reproducible by the swimmers. On the other hand, no differences on the $15 \mathrm{~m}$ start time performance are observed between the two techniques, confirming the high skill level of the swimmers, and notably their capability to compensate lower block efficiency by effective underwater phases. Indeed, the relative duration of the underwater phases, the number of leg undulations and arm strokes are very similar in both techniques.

\section{REFERENCES}

[1] Arellano R, Moreno FJ, Martinez M, Ona A. A device for quantitative measurement of starting time in swimming. In: Troup JP, Hollander AP, Strass D, Trappe SW, Cappaert JM, Trappe TA, Eds. Swimming Science VII; London, E and FN SPON 1996; pp. 195-200.

[2] Cossor JM, Mason BR. Swim start performances at the Sydney 2000 Olympic Games. In: Blackwell JR, Sanders RH, Eds. Proceedings of the XIX International Symposium on Biomechanics in Sports 2001 San Francisco, 2001; pp. 70-3.

[3] Sanders RH. Start technique - recent findings. Available from: http://www.education.ed.ac.uk/cis/swim/papers4/rs5.html

[4] Vilas-Boas JP, Cruz MJ, Sousa F, et al. Biomechanical analysis of ventral swimming starts: comparison of the grab start with two track start techniques. In : Chatard JC, Ed. Swimming Science IX 2002 ; Saint Etienne, France : University of Saint Etienne 2003; pp. 249-25.

[5] Ayalon A, Gheluwe B, Kanitz M. A comparison of four styles of racing in swimming. In: Clarys JP, Lewillie L, Eds. Swimming Science II. Baltimore: University Park Press 1975; pp. 233-40.

[6] Costill, DL, Maglischo EW, Richardson AB. Swimming. Oxford: Blackwell Scientific Publications 1992.

[7] Issurin V, Verbitsky O. Track start versus grab start: evidence from the Sydney Olympic Games. In : Chatard JC, Ed. Swimming Science IX, 2002; Saint Etienne, France: University of Saint Etienne; 2003; pp. 213-17.

[8] Bland M, Altman D. Measurement error and correlation coefficients. Br Med 1996; 313: 41-2.

(c) Vantorre et al.; Licensee Bentham Open.

This is an open access article licensed under the terms of the Creative Commons Attribution Non-Commercial License (http://creativecommons.org/licenses/by-nc/3.0/) which permits unrestricted, non-commercial use, distribution and reproduction in any medium, provided the work is properly cited. 